\title{
Incidence of cancer in a cohort of magnesium production workers
}

\author{
S S HELDAAS,' S LANGÅRD, ${ }^{2}$ A ANDERSEN ${ }^{3}$ \\ From the Health Department, ${ }^{1}$ Norsk Hydro a/s, and Department of Occupational Medicine, ${ }^{2}$ Telemark \\ Sentralsjukehus, N-3900 Porsgrunn, and Cancer Registry of Norway, ${ }^{3}$ Montebello, N-0310 Oslo 3, Norway
}

ABSTRACT The results from a cohort study on the incidence of cancer and the mortality in a cohort of 2391 male workers producing magnesium metal are presented. The study population was restricted to employees with more than one year of work experience in the study plant between 1951 and 1974 and the cohort was observed from 1953 to 1984 . Altogether 152 new cases of cancer were observed versus 132.6 expected. Six cases of cancer of the lip were found against 2.3 expected, 21 of stomach cancer against 12.8 expected, and 32 of lung cancer against 18.2 expected. A possible causal relation between exposure to factors in the work environment and the development of cancer is discussed.

The silver white metallic form of magnesium does not occur freely in nature. Large quantities of magnesium are found in sea water and in minerals such as dolomite, magnesite, olivine, and salt deposits.' There are several ways of producing magnesium metal and the production method depends on which type of raw material is available. The method for producing the magnesium metal used in the study plant is based on an electrolytic process. The world production of magnesium metal is small compared with steel and aluminium production.'

Production of magnesium metal necessitates the heating of carbonaceous material such as coal or coke, during which volatile coal tar products may be released. Coal tar is a mixture of different aromatic hydrocarbons. Chlorine gas is used in the chlorination process, where burned magnesium oxide is mixed with pulverised coke and subsequently treated with chlorine at high temperatures $\left(1100-1200^{\circ} \mathrm{C}\right)$. Chlorine gas combines with the coal tar products to form chlorinated products.

These possible exposure factors, together with the occurrence of hot metal fumes, asbestos insulation, irritant fumes, and dust, have given cause for concern about work related health hazards among the workers.

The total annual production of magnesium on a worldwide scale was about 270000 tons in 1976. In the study plant the annual production of magnesium metal increased from 226 tons during the first production year to $3000-5000$ tons a year in the 1950 s. By

Accepted 26 September 1988
1960 production was about 14000 tons and in 1962 production was started in a new chlorination and electrolysis hall which brought the capacity up to 40000 tons a year. By 1976 production accounted for $15 \%$ of the world total.' Since 1976 production has increased to 60000 tons.

The aim of the present study was to evaluate the risk of developing cancer associated with past work exposure at the plant and to attempt to differentiate between the different exposure factors in the plant by subdividing the study population into subgroups which, so far as possible, reflect specific exposure factors. So far as we are aware, no study has been published on the incidence of cancer or mortality among workers producing magnesium.

\section{Material and methods}

\section{PRODUCTION PROCESS}

The study plant is located in the county of Telemark in the south east of Norway. The company also manufactures polyvinyl chloride, chlorine, and fertilisers in adjacent plant complexes. Magnesium metal production was started in 1951 and is based on an electrolytic process. Dolomite and sea water are used as sources for magnesium. Figure 1 shows a flow sheet for the production process.

Crushed dolomite is burnt and subsequently mixed with sea water in large settling tanks. Magnesium hydroxide precipitates and is separated from the sea water, filtered and burnt, and subsequently magnesium oxide is formed. The oxide is mixed with pulverised coal or coke and combined with mag- 


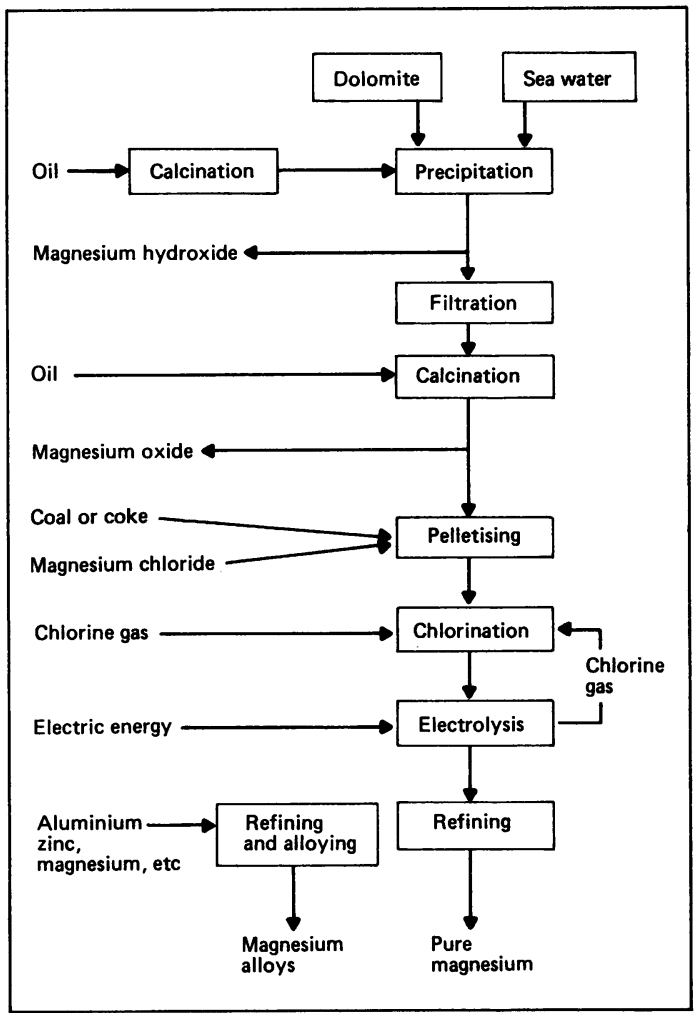

Fig 1 Flow sheet for magnesium production.

nesium chloride to form pellets. By heating the pellets to $1100-1200^{\circ} \mathrm{C}$, and then treating them with chlorine gas, magnesium oxide is converted to anhydrous magnesium chloride. The magnesium chloride is tapped at a temperature of $800^{\circ} \mathrm{C}$ and subsequently fed into electrolytic cells. The cells, which maintain a temperature of $750^{\circ} \mathrm{C}$, are bricklined steel shells with steel cathodes and carbon anodes. The metal is transferred to furnaces for refining and for alloying procedures. The alloying metals used are aluminium, manganese, zinc, and beryllium. The alloys are later cast into ingots, billets, or other shapes. ${ }^{1}$

\section{STUDY POPULATION}

A list, compiled from the personnel register provided by the plant, contained the names of employees with employment exceeding one month and who had been enrolled before the end of 1980 . The health department had kept records of present and previous workers employed from the first year of production onwards. These two sources of information were used and cross checked when the list of names was compiled. Based on experiences from previous studies among workers in the same company, ${ }^{2-4}$ the list was assumed to be complete.

The individual records contained the following information on each worker: name, date of birth? personal identity number, last known address, dates: for start and termination of employment, the depart-ments in the plant at which each person had worked and the duration of work in each department.

Individual data were obtained for 3912 workers. To avoid dilution, it was decided to restrict the cohort to male workers who had been employed for at least onew year. To avoid dilution by short term workers who haक 5 had no possibility of developing plant specificexposure related diseases, we also excluded all workersw who had first been employed in 1974 or later. These restrictions reduced the number of subjects to 2391 .

During the compilation of the list a separate register in the health department was discovered which con tained the names of all subjects who had received medical treatment for acute chlorine gas intoxication during the study period. It was decided to use theo individual exposure information in this register to identify an additional subgroup within the study.

\section{ESTIMATION OF EXPOSURE}

The production of magnesium metal and alloys 3 involves combined exposure to many potentially harmful agents. In the metallurgical process carbon $\overrightarrow{-0}$ aceous electrode material was heated and in chlorination process coal or coke were heated, both $-f_{0}$ which may release volatile coal tar pitch producto Coal tar, which is a mixture of various hydrocarbons, may combine with chlorine to form chlorinated hydrocarbons. Many different chlorinated aromaticso and polyaromatics have been isolated. Analysis of dust samples has shown hexachlorobenzene to be theö main chlorinated byproduct. Hexachlorobenzene 3 occurred at highest concentrations in the working atmosphere and has also been shown in discharges. from the plant. ${ }^{1}$

Other potential hazardous exposures were to asbes- $-\frac{\Phi}{3}$ tos, which was regularly used as an insulation materialoand for heat protection during the handling of liquid? metal, chlorine gas, carbon monoxide, and sulphurô dioxide. Dust containing magnesium oxide or chloride 3 exerts effects on skin and mucous membranes wheno reacting with moisture or sweat. In the electrolysis department a direct electric current of about $40-60 \mathrm{kA}$ 을 was used in the production of metal and chlorine. This electric current generated strong magnetic fields in the $\mathrm{G}$ work environment.

During interviews for occupational history the స్ట్ workers reported that the working atmosphere hado been heavily polluted by irritant gases and dust in the 1950 s and 1960s. No occupational hygiene survey had been performed before 1970. Asbestos was used as an@ 


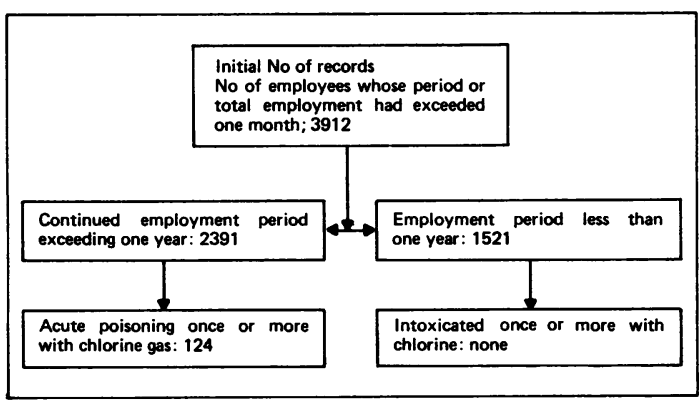

Fig 2 Summary of formation of study population.

insulation material until the early 1970 s. From 1975 onwards coke was substituted for coal in the chlorination process. Since coke generates little coal tar pitch, the exposure to chlorinated hydrocarbons must have been reduced, and monitoring and analysis of discharges from the plant indicated that the amount of chlorinated hydrocarbons had been reduced by as much as $90 \%$. $^{1}$

\section{JOB CLASSIFICATION}

Simultaneous exposure to several factors, some of which are known to be carcinogenic to man and animals (asbestos, hexachlorobenzene), has regularly taken place in the plant. In an attempt to characterise different categories of assumed monofactorial exposure and combined exposure, nine different exposure categories were defined. As we had little information about the possible carcinogenic potency of the different exposure factors, membership of an exposure category was generally defined as that category with the longest duration of work. Subjects with more than three years of work in the process of chlorination or electrolysis before the end of 1965 , however, were assigned to the "chlorination or electrolysis worker" category, irrespective of the duration of other jobs. This was to evaluate the cancer hazard in relation to exposure to presumed carcinogenic substances, such as asbestos and chlorinated hydrocarbons (hexachlorobenzene), combined with exposure to high temperatures and chlorine gas.

\section{REFERENCE ENTITY}

Those individuals who met the criteria for membership of the study population were compared with a constructed Norwegian population with an age distribution identical to that of the study group. ${ }^{5}$ Incidence of cancer and total mortality have been determined for the study population from 1953 to the end of 1984. The Cancer Registry of Norway has records of all new cases of cancer since 1953 and has access to information on causes of death which is provided by the Central Bureau of Statistics.

No separate reference population has been designed for this study. Calculation of the expected number of cases of cancer was based on the national five year age specific incidence rates. The male incidence rates for lung cancer and cancer of the lip in the population of the county of Telemark where the plant is located are about 1.3 and 1.2 respectively compared with national figures. ${ }^{6}$ The increased incidence rate for lung cancer, however, is fully explained by extensive use of asbestos in this area, ${ }^{7}$ and the excess incidence for cancer of the lip reflects the general/urban difference. Therefore there was no strong reason for preferring local rates as a reference entity to the robust national rates. The expected number of deaths are based on the national rates. Ninety five per cent confidence interval (CI) values have been estimated assuming a Poisson distribution for the observed number of cases.

\section{Results}

Table 1 shows the deaths from all causes and the number of new cases of cancer except basal cell

Table 1 Observed $(O)$ and expected $(E)$ deaths from all causes, and all new cases of cancer in the study population. Occupational category and exposure factors

\begin{tabular}{|c|c|c|c|c|c|c|}
\hline & Exposure categories & No of workers & $\begin{array}{l}\text { All deaths } \\
O / E\end{array}$ & $\begin{array}{l}\text { All cancers } \\
O / E\end{array}$ & SIR 95\% CI & $\begin{array}{l}\text { Person-years } \\
1953-84\end{array}$ \\
\hline $\begin{array}{l}01 \\
02 \\
+ \\
03\end{array}$ & $\begin{array}{l}\text { Magnesium oxide (MgO, coal dust) } \\
\text { Chlorination and electrolysis } \\
\text { (asbestos, hexachlorobenzene } \\
\text { ( } \mathrm{HCB}) \mathrm{Cl}, \mathrm{MgCl}, \mathrm{HCl} \text {, heat) }\end{array}$ & $\begin{array}{r}393 \\
1139\end{array}$ & $\begin{array}{c}68 / 74 \cdot 3 \\
173 / 159 \cdot 7\end{array}$ & $\begin{array}{l}35 / 25 \cdot 2 \\
63 / 54 \cdot 2\end{array}$ & $\begin{array}{l}1.0-1.9 \\
0.9-1.4\end{array}$ & $\begin{array}{r}9082 \cdot 0 \\
24366 \cdot 5\end{array}$ \\
\hline $\begin{array}{l}05 \\
06 \\
07\end{array}$ & $\begin{array}{l}\text { Foundry work (Mg, } \mathrm{SO}_{2} \text { heat) } \\
\text { Research and laboratory work } \\
\text { Maintenance work } 02,03 \text { and } 05 \\
\text { (asbestos, heat. } \mathrm{HCB}, \mathrm{Cl} \text { SO, }\end{array}$ & $\begin{array}{l}228 \\
121 \\
316\end{array}$ & $\begin{array}{l}39 / 43 \cdot 1 \\
5 / 12 \cdot 3^{*} \\
48 / 53 \cdot 4\end{array}$ & $\begin{array}{c}20 / 15 \cdot 8 \\
3 / 4 \cdot 7 \\
14 / 19 \cdot 0\end{array}$ & $\begin{array}{l}0.1-1 \cdot 9 \\
0 \cdot 1-1 \cdot 9 \\
0.4-1 \cdot 2\end{array}$ & $\begin{array}{l}4879 \cdot 5 \\
2499 \cdot 5 \\
7499 \cdot 5\end{array}$ \\
\hline $\begin{array}{l}08 \\
09\end{array}$ & $\begin{array}{l}\text { Brick work etc (HCB, Cl heat) } \\
\text { Maintenance work } 01 \text { (MgO, C, } \\
\text { asbestos) }\end{array}$ & $\begin{array}{l}62 \\
64\end{array}$ & $\begin{array}{c}6 / 9 \cdot 9 \\
13 / 12 \cdot 6\end{array}$ & $\begin{array}{l}2 / 3 \cdot 7 \\
4 / 4 \cdot 4\end{array}$ & $\begin{array}{l}0 \cdot 3-2 \cdot 4 \\
0 \cdot 3-2 \cdot 3\end{array}$ & $\begin{array}{l}1416.0 \\
1464.5\end{array}$ \\
\hline \multirow[t]{2}{*}{00} & Various jobs (packing office) & 68 & $18 / 18 \cdot 4$ & $11 / 5 \cdot 8$ & $0 \cdot 9-3 \cdot 4$ & $1526 \cdot 0$ \\
\hline & Total & 2391 & $370 / 383 \cdot 8$ & $152 / 132 \cdot 6$ & $0 \cdot 9-1 \cdot 5$ & 52733 \\
\hline
\end{tabular}

$* 95 \% \mathrm{CI}=0 \cdot 13-1 \cdot 0$. 
Table 2 Observed $(O)$ and expected $(E)$ number of selected types of cancer in study population 1953-84

\begin{tabular}{|c|c|c|c|c|}
\hline Cancer site (ICD) & $(0)$ & (E) & $\boldsymbol{R} R$ & $95 \% \mathrm{CI}$ \\
\hline $\operatorname{Lip}(140)$ & 6 & $2 \cdot 3$ & $2 \cdot 6$ & $1 \cdot 0-5 \cdot 7$ \\
\hline Oesophagus (150) & 2 & 1.6 & $1 \cdot 3$ & $0.1-4.5$ \\
\hline Stomach (151) & 21 & $12 \cdot 8$ & 1.6 & $1 \cdot 0-2 \cdot 4$ \\
\hline Colon (153) & 8 & $10 \cdot 0$ & 0.8 & $0.4-2.0$ \\
\hline Rectum (154) & 7 & 6.8 & 1.0 & $0 \cdot 4-2 \cdot 1$ \\
\hline Lung $(162 / 163)$ & 32 & $18 \cdot 2$ & 1.8 & $1 \cdot 2-2 \cdot 5$ \\
\hline Prostate (177) & 20 & $17 \cdot 2$ & $1 \cdot 2$ & $0.7-1.8$ \\
\hline Testis (178) & 4 & $3 \cdot 5$ & $1 \cdot 1$ & $0 \cdot 3-2 \cdot 9$ \\
\hline Kidney (180) & 7 & $5 \cdot 4$ & $1 \cdot 3$ & $0 \cdot 5-2 \cdot 7$ \\
\hline Bladder (181) & 10 & 8.6 & 1.2 & $0 \cdot 6-2 \cdot 1$ \\
\hline $\begin{array}{l}\text { Malignant melanoma of the skin } \\
(190)\end{array}$ & 5 & $5 \cdot 6$ & 0.9 & $0 \cdot 3-2 \cdot 1$ \\
\hline $\begin{array}{l}\text { Skin (excluding basal cell cancer) } \\
\text { Leukaemia }(204-206)\end{array}$ & $\begin{array}{l}6 \\
7\end{array}$ & $\begin{array}{l}5 \cdot 7 \\
5 \cdot 4\end{array}$ & $\begin{array}{l}1 \cdot 0 \\
1 \cdot 3\end{array}$ & $\begin{array}{l}0.4-2 \cdot 3 \\
0.5-2 \cdot 7\end{array}$ \\
\hline Total & 152 & 132.6 & $1 \cdot 1$ & $0.9-1 \cdot 5$ \\
\hline
\end{tabular}

carcinoma of the skin. The number of person-years under observation is also shown with a tabulation of eight different exposure categories. Among the 2391 men there were 370 deaths from all causes versus 383.8 expected. During the 32 year observation period 152 new cases of cancer had occurred versus 132.6 expected. Table 2 shows some selected sites of cancer. A statistically significant excess of lung cancer $(\mathbf{R R}=$ $1.8)$ and a borderline statistically significant excess of lip cancer $(R R=2.6)$ and stomach cancer $(R R=1.6)$ were observed.

Table 3 shows the observed and expected number of selected types of cancer according to three occupational categories. In the chlorination and electrolysis categories were three cases of lip cancer versus 1.2 expected $(R R=2 \cdot 5)$. Ten cases of stomach cancer were observed versus 5.2 expected $(R R=1 \cdot 9)$. Lung cancer was also in excess in this subgroup; 15 cases versus 7.5 expected $(R R=2.0)$. The main occupational disease determinants to which this sub-市 group was exposed are asbestos, chlorine gas, dust - . containing metal chlorides, hexachlorobenzene, heat, $\overrightarrow{\overline{\vec{F}}}$ and magnetic field. Among workers in the foundry were four cases of lung cancer versus $2 \cdot 1$ expected (RR듬 $=1.9$ ). Sulphur dioxide, heat, magnesium metal, and $\overline{\bar{n}}$ magnesium alloys had been the main exposure factors at this worksite. Among the workers in the third subgroup, whose main exposure factors had beencs magnesium oxide and dust containing carbon (coal), $\vec{\circ}$ six cases of lung cancer were observed versus 3.5 expected $(R R=1 \cdot 7)$.

Table 4 presents the number of observed ando expected cases of selected cancers by duration of employment. Cancer of the lung and cancer at all sites showed increasing rate ratios with increasing duration of employment. The results for lung cancer were; statistically significant both for all employment $\overrightarrow{-}$ periods and for an employment period longer than 200 years. Lip cancer occurred with the highest rate ratioamong workers with short employment time, whereases cancer of the stomach showed the highest rates in the $\mathbb{8}$ workers with short and medium employment稌 experience.

Table 5 presents the observed and expected cases of selected cancer sites in two different employment $\overrightarrow{0}$ periods (1950-9 and 1960-9), stratified by year singee first employment. No obvious difference between the two employment periods can be seen which may refieto a lack of major changes in occupational exposure factors over these periods. Both for lip cancer and lungo cancer the highest rate ratios are seen if latency periods

Table 3 Observed $(O)$ and expected $(E)$ cases of selected types of cancer and all new cases of cancer among three occupational categories. $C I$ is not presented when the observed figures were less than one

\begin{tabular}{|c|c|c|c|c|c|c|c|c|}
\hline & \multicolumn{2}{|c|}{$\operatorname{Lip}(I C D 140)$} & \multicolumn{2}{|c|}{ Stomach (ICD 15I) } & \multicolumn{2}{|c|}{ Lung (ICD 162/163) } & \multicolumn{2}{|c|}{ All cancers (ICD 140-209) } \\
\hline & $O / E$ & $95 \% \mathrm{CI}$ & $O / E$ & $95 \% \mathrm{CI}$ & $O / E$ & $95 \% C I$ & $O / E$ & $95 \% \mathrm{CI}$ \\
\hline $\begin{array}{l}\text { Chlorination electrolysis } \\
\text { Foundry work } \\
\text { Magnesium oxide } \\
\text { Other departments }\end{array}$ & $\begin{array}{l}3 / 1 \cdot 3 \\
1 / 0 \cdot 3 \\
1 / 0 \cdot 4 \\
1 / 0 \cdot 3\end{array}$ & $\begin{array}{l}0 \cdot 1-6 \cdot 8 \\
- \\
-\end{array}$ & $\begin{array}{r}10 / 5 \cdot 2 \\
3 / 1 \cdot 5 \\
5 / 2 \cdot 5 \\
3 / 3 \cdot 6\end{array}$ & $\begin{array}{l}0.9-3.5 \\
0.6-4.5 \\
0.2-2.8\end{array}$ & $\begin{array}{r}15 / 7 \cdot 5 \\
4 / 2 \cdot 1 \\
6 / 3 \cdot 5 \\
7 / 5 \cdot 1\end{array}$ & $\begin{array}{l}1 \cdot 1-3 \cdot 2 \\
0.5-4.9 \\
0.6-3 \cdot 7 \\
0.5-2.8\end{array}$ & $\begin{array}{l}63 / 54 \cdot 8 \\
21 / 15 \cdot 2 \\
36 / 24 \cdot 9 \\
32 / 37 \cdot 1\end{array}$ & $\begin{array}{l}0 \cdot 9-1 \cdot 4 \\
0 \cdot 9-2 \cdot 1 \\
1 \cdot 0-2 \cdot 0 \\
0 \cdot 5-1 \cdot 2\end{array}$ \\
\hline Total & $6 / 2 \cdot 3$ & $1 \cdot 0-5 \cdot 7$ & $21 / 12 \cdot 8$ & $1 \cdot 0-2 \cdot 4$ & $32 / 18 \cdot 4$ & $1 \cdot 2-2 \cdot 5$ & $152-132 \cdot 6$ & $0.9-1.5$ \\
\hline
\end{tabular}

Table 4 Observed $(O)$ and expected $(E)$ cases of selected types of cancer and all new cases of cancer according to duration of employment

\begin{tabular}{|c|c|c|c|c|c|c|c|c|}
\hline \multirow[b]{2}{*}{ Employment period $(y)$} & \multicolumn{2}{|c|}{ Lip (ICD I40) } & \multicolumn{2}{|c|}{ Stomach (ICD 15I) } & \multicolumn{2}{|c|}{ Lung (ICD 162/163) } & \multicolumn{2}{|c|}{ All cancers (ICD 140-209) } \\
\hline & $O / E$ & $95 \% C I$ & $O / E$ & $95 \% \mathrm{CI}$ & $O / E$ & $95 \% \mathrm{CI}$ & $O / E$ & $95 \% \mathrm{CI}$ \\
\hline$\underbrace{10}_{20} 19$ & $\begin{array}{l}5 / 1 \cdot 6 \\
1 / 0 \cdot 5 \\
0 / 0 \cdot 2\end{array}$ & $\begin{array}{l}1 \cdot 0-7 \cdot 3 \\
-\end{array}$ & $\begin{array}{r}14 / 8.9 \\
5 / 2.8 \\
2 / 1 \cdot 1\end{array}$ & $\begin{array}{l}0.9-2 \cdot 6 \\
0.6-4 \cdot 2 \\
0.2-6.5\end{array}$ & $\begin{array}{c}15 / 12 \cdot 0 \\
7 / 4 \cdot 1 \\
10 / 2 \cdot 1\end{array}$ & $\begin{array}{l}0 \cdot 6-2 \cdot 1 \\
0 \cdot 7-3 \cdot 5 \\
2 \cdot 3-8 \cdot 8\end{array}$ & $\begin{array}{l}87 / 90.6 \\
47 / 28.4 \\
18 / 13.6\end{array}$ & $\begin{array}{l}0 \cdot 8-1 \cdot 1 \\
1 \cdot 2-2 \cdot 2 \\
0 \cdot 8-2 \cdot 1\end{array}$ \\
\hline Total & $6 / 2 \cdot 3$ & $1 \cdot 0-5 \cdot 7$ & $21 / 12 \cdot 8$ & - & $32 / 18 \cdot 2$ & $1 \cdot 2-2 \cdot 5$ & $152 / 132 \cdot 5$ & - \\
\hline
\end{tabular}


Table 5 Observed $(O)$ and expected $(E)$ cases of selected types of cancer and all new cases of cancer stratified by years from first employment and employment entry

\begin{tabular}{|c|c|c|c|c|c|}
\hline \multirow[b]{2}{*}{$\begin{array}{l}\text { Employ- } \\
\text { ment entry }\end{array}$} & \multirow[b]{2}{*}{ Cancer site } & \multicolumn{4}{|c|}{ Years from first employment } \\
\hline & & $\begin{array}{l}1-9 \\
O / E\end{array}$ & $\begin{array}{l}10-19 \\
O / E\end{array}$ & $\geqslant 20$ & $\begin{array}{l}\text { Total } \\
O / E\end{array}$ \\
\hline $1951-9$ & $\begin{array}{l}\text { All cancers } \\
\text { Lip }(140) \\
\text { Lung }(162-163) \\
\text { Stomach }(151)\end{array}$ & $\begin{array}{l}8 / 7 \cdot 7 \\
0 / 0 \cdot 2 \\
3 / 0 \cdot 7 \\
0 / 1 \cdot 3\end{array}$ & $\begin{array}{c}28 / 20 \\
1 / 0 \cdot 4 \\
2 / 2 \cdot 7 \\
4 / 2 \cdot 6\end{array}$ & $\begin{array}{c}48 / 49 \\
2 / 0 \cdot 7 \\
14 / 7 \cdot 2^{*} \\
6 / 4 \cdot 2\end{array}$ & $\begin{array}{l}84 / 76 \cdot 8 \\
3 / 1 \cdot 4 \\
19 / 10 \cdot 7 \dagger \\
10 / 8 \cdot 1\end{array}$ \\
\hline $1960-9$ & $\begin{array}{l}\text { All cancers } \\
\text { Lip }(140) \\
\text { Lung }(162-163) \\
\text { Stomach }(151)\end{array}$ & $\begin{array}{c}14 / 14 \cdot 3 \\
1 / 0 \cdot 2 \\
0 / 1 \cdot 7 \\
7 / 1 \cdot 5\end{array}$ & $\begin{array}{c}34 / 30 \cdot 1 \\
1 / 0 \cdot 5 \\
8 / 4 \cdot 3 \\
4 / 2 \cdot 4\end{array}$ & $\begin{array}{l}15 / 5 \cdot 3 \\
1 / 0 \cdot 06 \\
3 / 3 \cdot 8 \\
0 / 0 \cdot 4\end{array}$ & $\begin{array}{c}63 / 49 \cdot 7 \\
3 / 0 \cdot 8 \\
11 / / 6 \cdot 8 \\
11 / 4 \cdot 3\end{array}$ \\
\hline
\end{tabular}

*95\% CI $=1 \cdot 1-3 \cdot 3$

$+95 \% \mathrm{CI}=1 \cdot 1-2 \cdot 8$.

of 20 years are introduced to both entry periods. The incidence of cancer of the stomach showed no obvious relation with number of years from first employment nor the period for employment entry. For those who were first employed during 1950-9, the highest rate ratios (not shown) were seen more than 10 and 20 years after first employment, whereas the situation was opposite for the workers first employed in 1960-9. Employment entry after 1970 was not included as the observation time was considered to be too short.

In table 6 the observed and expected figures are presented for all new cancers and selected cancer sites in the small subgroup who had experienced chlorine gas intoxication. Four cases of lung cancer had occurred versus 1.3 expected among the members of this group. Table 7 shows the distribution and duration of exposure in the different exposure categories among workers in whom cancer of the lip has been diagnosed. Exposure to irritative dust or fumes had occurred frequently in the categories to which those who had died had belonged.

\section{Discussion}

Thirty nine per cent of the former employees left employment before the end of the year. Some may
Table 6 Observed $(O)$ and expected $(E)$ cancer of selected sites and all new cases of cancer for those listed in the chlorine intoxication register only

\begin{tabular}{|c|c|c|c|c|c|}
\hline & \multicolumn{2}{|c|}{$\begin{array}{l}\operatorname{Lip} \\
(I C D \text { 140) }\end{array}$} & \multicolumn{2}{|c|}{$\begin{array}{l}\text { Lung } \\
\text { (ICD 162-163) }\end{array}$} & \multirow{2}{*}{$\begin{array}{l}\text { All cancers } \\
(I C D \text { 140-209) } \\
O / E\end{array}$} \\
\hline & $O / E$ & CI 95\% & $O / E$ & CI $95 \%$ & \\
\hline $\begin{array}{c}\text { Chlorine } \\
\text { gas (+) }\end{array}$ & $0 / 0 \cdot 1$ & - & $4 / 1 \cdot 3$ & $0.8-7.8$ & $10 / 9 \cdot 7$ \\
\hline $\begin{array}{l}\text { Chlorine } \\
\text { gas (-) }\end{array}$ & $6 / 1 \cdot 1$ & $2 \cdot 0-11.9$ & $28 / 16 \cdot 8$ & $1 \cdot 1-2 \cdot 4$ & $144 / 122 \cdot 5$ \\
\hline
\end{tabular}

have left for reasons of poor health, leaving selected groups of workers in the study cohort who may therefore be assumed to be healthier than the general population. There had also been a health selection in the recruitment of the workers. The medical records gave many case histories in which workers with lung disease were advised not to take employment in the plant. Some employees with frequent sick leave during the first year of employment for reasons such as bronchitis were also advised to leave.

Although the national rates for incidence of cancer and death as a reference entity in the present study are correct figures and may be considered robust, we are well aware that the application of these rates as a reference entity is a weak point in the study. The national population has been exposed to a great number of different cancer causing agents of which we have no knowledge. When using this reference entity the deficit in mortality of all causes was moderate, 370 versus 383.8 expected, which may indicate that the preselection and early employment health selection were insufficient to compensate for a presumed increased risk of mortality in the cohort (table 1). Based on the presence of known exposure to carcinogenic agents such as asbestos and hexachlorobenzene in the magnesium metal production, one might expect an increased incidence of cancer in the subgroups exposed to those agents (tables 1 and 3 ).

The excess of lip cancer (table 2) seems to be associated with different occupational categories (table 7). Chemicals such as magnesium oxide dust,

Table 7 Distribution of exposure categories among workers in whom cancer of the lip has been diagnosed. Figures give duration of exposure under different categories in years

\begin{tabular}{|c|c|c|c|c|c|c|c|c|c|c|}
\hline \multirow{2}{*}{$\begin{array}{l}\text { Age when cancer } \\
\text { was diagnosed }\end{array}$} & \multirow{2}{*}{$\begin{array}{l}\text { Date of first } \\
\text { employment }\end{array}$} & \multirow{2}{*}{$\begin{array}{l}\text { Year of } \\
\text { diagnosis }\end{array}$} & \multicolumn{8}{|c|}{ Exposure category (table I) } \\
\hline & & & 00 & 01 & $02+03$ & 05 & 06 & 07 & 08 & 09 \\
\hline $\begin{array}{l}65 \\
64 \\
38 \\
67 \\
54^{*} \\
65+\end{array}$ & $\begin{array}{l}1952 \\
1952 \\
1958 \\
1961 \\
1963 \\
1967\end{array}$ & $\begin{array}{l}1975 \\
1979 \\
1971 \\
1981 \\
1965 \\
1983\end{array}$ & & 14 & $\begin{array}{l}1 \\
5 \\
1\end{array}$ & 4 & & 3 & & \\
\hline
\end{tabular}

*History of metal from welding to lip.

†History of Herpes lab. 
coal dust, chlorine gas, hydrochlorine aerosols, chlorinated aromatics, and sulphur dioxide were common in all the workplaces from which the cases of cancer were recruited (tables 1 and 7).

Until the late 1970s a mouthpiece was used as a protective device for the respiratory tract and many workers told how they had a sore mouth and lip line mucosa when this was used. These mouthpieces which all workers carried around their neck or in their pocket in case of unexpected exposure to chlorine gas were regularly cleaned with purified benzine, which usually contains $n$-hexane and at least trace amounts of benzene. So far one can only speculate about the significance of the use of this solvent on the development of lip cancer.

Dental status was screened during the early 1980 s to evaluate the possible hazards to soft and hard oral tissues. Among 34 surveyed workers, the prevalence of oral mucous membrane and lip line defects was $38 \%$. The observed disturbances included inflammation, pale membranes, leukoplakia, epithelial defects on underlips, and injection of the mucosal membranes inside the underlip. Injection of the mucous membranes seemed to be associated with smoking habits. The possible association with the use of the mouthpiece and defects of the lip deserves further attention. ${ }^{8}$

Among the subjects who had developed lip cancer, three had a history of cigarette smoking. This information was available in the records at the health department of the company. No information was available on the smoking habits of the other three cases. Smoking as a separate causal exposure factor, or as a factor interacting with work related exposure, may therefore be considered. The incidence of cancer of the lips is about 1.2 compared with the national rates but the additional cases in the present study account for only about one fifth of the local excess.

Oral soft and hard tissue diseases have been observed by different authors in relation to occupational exposures. An association has been observed between exposure to acid aerosols and dental erosions among battery workers'; increased risk of cancer of the underlip among fishermen ${ }^{10}$; increased mortality or oral and pharyngeal cancers among male newspaper printers ${ }^{11}$; and increased risk of oral cancer among textile workers. ${ }^{12}$ The prevalence of pigmented teeth was $30 \%$ among printers exposed to organic solvents and pigments versus $6 \%$ among controls. ${ }^{13}$ Bekmetov found an increased incidence rate of mouth and lip line mucosa leukoplakia in mineral fertiliser production workers who had been exposed to toxic irritant chemicals such as fluoride, ammonia, nitrogen oxides, or ammonium nitrate. ${ }^{14} \mathrm{He}$ suggested that mouth leukoplakia should be considered as an occupational illness when occurring in these workers.

In the present study an increased incidence of lip cancer was seen in the two periods (table 5) of befor $\bar{C}$ 1959 and during 1960-9. The highest rate ratio was seen among workers with the shortest duration of employment (table 4). From the individua? occupational histories we became aware of the use of promotion to other jobs after work in a job with high exposure to irritative gases, dust, and heat. After some years of such working conditions the workers wer offered the opportunity to be transferred to a lesष्ष polluted work area in the plant. To some extent thi尺 job circulation explains the observed inverse "exposure response" relation.

The statistical significance of the excess of stomach cancer in the cohort is borderline. Two recent Nor $\vec{\omega}$ wegian reports on the incidence of cancer in workers ing the ferroalloy industry ${ }^{15}$ and workers producing cal cium carbide ${ }^{16}$ observed a deficit of stomach cancer and the authors suggested that exclusion from shift work of workers with gastric symptoms was a possible explanation. An excess of stomach cancer was however, observed in a study among Norwegian ferrochromium workers. ${ }^{17}$ Shift work has been com? mon in the present magnesium metal plant, and many workers who had gastric symptoms had been offered daytime jobs or had left the plant. Increased incidencee of stomach cancer seems to be associated with medium long duration of employment, which migh@ have led to a job selection for subjects with gastrie symptoms (table 4). The excess incidence of stomatpo cancer also seems to be associated with work chlorination and electrolysis (table 3). Asbestos a⿳亠丷厂巾 chemicals such as chlorine gas, hydrochloric aerosots and chlorinated aromatics had been the main exposure factors at these worksites.

Asbestos had been used as an insulation materiab around the furnaces and around bricks in the cells $\overrightarrow{\overrightarrow{0}}$ which is of interest for the increased incidence of lung cancer in this cohort (tables 2, 3, and 4). Combined exposure to asbestos and chlorinated coal tar pitch compounds such as hexachlorobenzene and irritan $\bar{\sigma}$ gases such as chlorine or sulphur dioxide, has occurred among the members of this cohort. No published information is available on the possible hazards of lung cancer such exposure combinations may con stitute.

The number of years of employment (table 4) andb the number of years since first employment (table 5) strengthened the association between employment ato the plant and the risk of lung cancer. The highest ratesof lung cancer were seen in workers with the longestr duration of employment. Adequate occupational and medical histories were available at the company'sิ health department for 17 of the 32 cases of lung cancer $\omega$ Combined exposure to asbestos and tobacco smoking had taken place in all 17 cases. The exposure information in the health records of these 17 subjects indicateds 
tion in the health records of these 17 subjects indicated that exposure to asbestos had been a significant occupational exposure factor. Although no information on exposure to asbestos was available for the other 15 cases, the positive asbestos information in those 17 with good occupational histories indicates that asbestos might have played a significant aetiological part in the development of lung cancer in this cohort. No information was available on the level of exposure to asbestos in this plant but asbestos was in common use up to the late 1970s.

Four cases of lung cancer were recruited from the small subgroup with a history of chlorine intoxication versus $1 \cdot 3$ expected (table 6 ), which could suggest the presence of lung cancer hazards in this subgroup in addition to exposure to asbestos. The rate ratios for lip cancer and lung cancer were higher in those workers who were not registered in the chlorine exposure list than among the chlorine intoxicated subjects. The application of protective garments (mouthpieces) may be one speculative reason for this difference.

\section{References}

1 Anonymous. Twenty-five years of magnesium. Porsgrunn: Norsk Hydro Ltd, 1976:6.

2 Heldaas SS, Langård S, Andersen A. Incidence of cancer among vinyl chloride and polyvinyl chloride workers. $\mathrm{Br} J$ Ind Med 1984;41:25-30.

3 Hilt B, Langård S, Andersen A, Rosenberg J. Asbestos exposure, smoking habits and cancer incidence among production and maintenance workers in an electrochemical plant. Am J Ind Med 1985;8:565-77.

4 Heldaas SS, Andersen A, Langård S. Incidence of cancer among vinyl chloride and polyvinyl chloride workers: an extended follow up study. Br J Ind Med 1987;44:278-80.

5 Pedersen E, Hфgetveit AC, Andersen A. Cancer of respiratory organs among workers at a nickel refinery in Norway. Int $J$ Cancer 1973;12:32-41.

6 Cancer Registry of Norway. Incidence of cancer in Norway 19721976. Oslo: Norwegian Cancer Society, 1978.

7 Kjuus H, Skjærven R, Langård S, Lien JT, Aamot T. A casereferent study of lung cancer, occupational exposures and smoking. II. Role of asbestos exposure. Scand J Work Environ Health 1986;12:203-9.

8 Jorkjend L. Dentale forhold hos arbeidere ved en norsk bedrift. Del 1. Slimhinneforandringer hos personer med egne tenner. Norske Tannlaegeforenings Tidende 1979;89:196-200. (In Norwegian.)

9 Cate HJTB. Dental mission in industry. Br J Ind Med 1968;25: $249-66$.

10 Spitzer WO, Hill GB, Chambers LW, Helliwell BE, Murphy BE. The occupation of fishing as a risk factor in cancer of the lip. $N$ Engl J Med 1975;293:419-24.

11 Lloyd JW, Decoufle P, Salvin LG. Unusual mortality experience of printing press men. J Occup Med 1977;19:543-50.

12 Moss E, Lee WR. Occurrence of oral and pharyrgeal cancers in textile workers. Br J Ind Med 1974;31:224-32.

13 Larsen VK. Hvad ved vi om arbejdsbetingede mundhulelidelser? Ugeskr Laeger 1983;145:913-5. (In Danish.)

14 Bekmetov MV. Leukoplakia of the oral mucosa in chemical workers. Stomatologiias (Mosk) 1983;62:35-7. (In Russian.)

15 Kjuus H, Andersen A, Langård S, Knudsen K. Cancer incidence among workers in the Norwegian ferroalloy industry. $\mathrm{Br} J$ Ind Med 1986;43:227-36.

16 Kjuus H, Andersen A, Langård S. Incidence of cancer among workers producing calcium carbide. $\mathrm{Br} \mathrm{J}$ Ind $\mathrm{Med}$ 1986;43: 237-42.

17 Langard S, Andersen A, Ravnestad J. Incidence of cancer among ferrochromium and ferrosilicon workers: an extended observation period. $\mathrm{Br} J$ Ind $\mathrm{Med}$ (in press). 